\title{
Proceeding
}

Supplementary Issue: Summer Conferences of Sports Science. First International Conference in Iraq on Sport for Peace, 4 April 2019. Baghdad Science Institute, Baghdad, Iraq.

\section{How the adoption of sustainable technology affects the organizational performance of SMEs in Thai Sports industry}

\author{
SAKAPAS SAENGCHAI ${ }^{1}$, MANEERAT MITPRASAT ${ }^{2}$, KITTISAK JERMSITTIPARSERT ${ }^{3,4}$ \\ ${ }^{1}$ Faculty of Humanities and Social Science, Suan Sunandha Rajabhat University, Bangkok, Thailand \\ ${ }^{2}$ Political Science Association, Kasetsart University, Bangkok, Thailand \\ ${ }^{3}$ Department for Management of Science and Technology Development, Ton Duc Thang University, Ho Chi \\ Minh City, Vietnam \\ ${ }^{4}$ Faculty of Social Sciences and Humanities, Ton Duc Thang University, Ho Chi Minh City, Vietnam
}

\begin{abstract}
In the current study we have tested the model of modern theoretical research for the adoption of sustainable technology and by the adoption organization's expected outcomes. We have investigated the four factors government aid, organizational belief, organizational influences and organizational attitudes to see how these factors affect the decisionmaking process of the organizations with the adoption of sustainable technology. The study is carried out on the sports SMEs of Thailand. The final sample comprises of 317 respondents and SEM-PLS is used to analyse the data The results of the current study have supported the theoretical model of advanced research for the adoption of sustainable technology and confirmed the comparative contribution of the independent variables to the acceptance of changes in organizational sustainable technology. The study highlights that As SME's are important for the Thai economy so they can improve the organizational performance by adopting the sustainable technology. The government of Thailand has started to provide special trainings and incentives which will boost the nonstop contribution with innovation. The results of the current study will contribute to an improved theoretical consideration of the antecedents which effect the adoption of sustainable technology and its apparent outcomes. It provides practical implications for the NGOs and government as well. We have combined the Multiple variables in a single study which were used by different scholars in adoption related studies. Keywords: Sustainability; Technology; Sports SMEs; Thailand.
\end{abstract}

\section{Cite this article as:}

Saengchai, S., Mitprasat, M., \& Jermsittiparsert, K. (2019). How the adoption of sustainable technology affects the organizational performance of SMEs in Thai Sports industry. Journal of Human Sport and Exercise, 14(5proc), S2157-S2171. doi:https://doi.org/10.14198//hse.2019.14.Proc5.36

Corresponding author. Department for Management of Science and Technology Development, Ton Duc Thang University, Ho Chi Minh City, Vietnam.

E-mail: kittisak.jermsittiparsert@tdtu.edu.vn

Supplementary Issue: Summer Conferences of Sports Science. First International Conference in Iraq on Sport for Peace, 4 April 2019. Baghdad Science Institute, Baghdad, Iraq.

JOURNAL OF HUMAN SPORT \& EXERCISE ISSN 1988-5202

(C) Faculty of Education. University of Alicante

doi:10.14198/jhse.2019.14.Proc5.36 


\section{INTRODUCTION}

All over the world new innovations and technologies are being revealed day by day. Different research projects are persistently and continuously conducted by several organizations including research institutions, universities and companies. From now by changing the creativity levels different innovations are produced. Any attempt can bring new findings which drives consideration in science or may create new applications for innovations and technologies. Behind the economic growth and its importance in developed and developing countries these accomplishments are the reason. Certainly, usually with the introduction of new technology the public provokes some resistance. For the organizations the acceptance of severe changes, which effect their daily production or lifestyle is difficult (Tidd \& Bessant, 2018). By keeping this view, the current study will concentrate on attitude of organizations towards innovations which are different from their existing practices and after that will also explore and understand the development process in organizations. Within the organizations by adopting the new technological innovations leads towards self-cautious which results in changed attitudinal terms (Lechevalier, Debanes, \& Shin, 2018). By understanding these transformations will also high light the different factors for the process of active adoption. Additionally, in the organizations these attitudes will produce the different degrees for accepting the new technology. The updated phenomenon make contribution in new challenges in organizations. It also suggests the new business opportunities for generating the new products and services by making a value addition in prevailing processes. With the technological innovations the organizational engagement has been improved by exiting knowledge-based economy. Due to the short life cycle of the product, globalization and marketing the business competition is increasing (Tidd \& Bessant, 2018). Many studies have explored the different opportunities and challenges which come across for the adoption of modern technologies in organizations, and divide them in three levels: lifestyle, community and society experiences. For the development of new system and managerial technologies in the organizations these results assist as motivation (Chenhall \& Moers, 2015). Besides the importance of technological innovations and their importance, literature also shown that it may cause unrestrained development. Due to these factors there will be a burden on environment which will lead towards social and environmental issues. Environment will be effected badly with increasing demand of natural resources whereas the absence of such resources will decrease the operational performance of the organization (Rothenberg, Hull, \& Tang, 2017). Bakar (2017) has explored that most of the raw materials used internationally are still originated from the resources which are non-renewable. Due to the degradation of environment, pollution and diminishing of natural resources have transferred the existing flow of originated sustainable substitutes and technological innovation. The organizations are trying to produce ad manufacture those commodities and services which are sustainable and valuable as well, now a days as per demand of customers in competitive international market for fighting against environmental harm. The current study is conducted on supports SME's of Thailand.

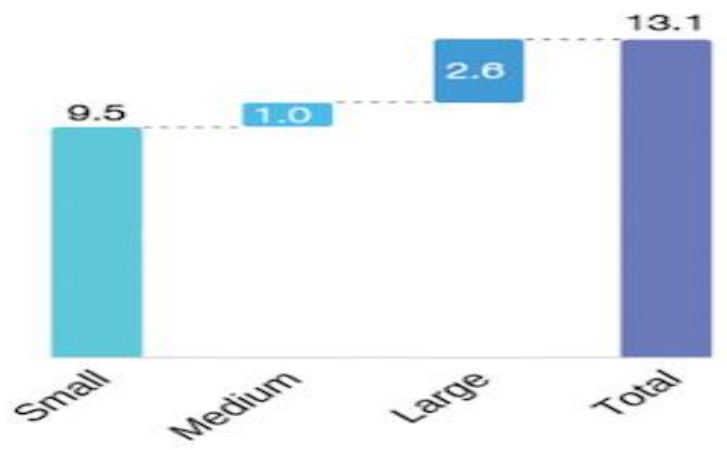

Source of Ministry of Commerce Thailand.

Figure 1. Sports SMEs growth in 2018. 
As SME's are important for the Thai economy so they can improve the organizational performance by adopting the sustainable technology. The government of Thailand has started to provide special trainings and incentives which will boost the nonstop contribution with innovation (Lechevalier et al., 2018). Although acquiring the resources is arduous task but SME's are preliminary opening their mind about sustainable technology. For the adoption of any innovation it is very important to make may considerations for example risk, investments and benefits. SME's can be medium, small and micro, and according to the profit shares and objectives all three are different from each other. From the micro prospective organizations mostly have business for fulfilling their everyday needs or requirements, and most of them are not interested in adoption of sustainable technology because it required high investment, time and risk, whereas medium size organizations can take the risk in adoption of sustainable technology to expand their business as they take high profit margins (Karim, Phillips, \& Belton, 2014). Mostly SME's are attentive for adoption of modern technology, but associated risk factor with adoption is the reason of reconsideration. By using the qualitative method for the collection of data the current study will focus on SME's of Thailand in different sectors. Collection of data from various sectors will allow to explore the about SME's observations of sustainable technology from different organizations and from the people who have different experiences and background (Karim et al., 2014).

\section{HYPOTHESIS DEVELOPMENT}

Affective attitudes are generally associated with the emotional state of human. González-Hidalgo and Zografos (2019) stated that affective attitude is the occurrence of human reactions while come across important association with environments and others. The affective attitude inclines to depend on emotions of an organization and attentive on their environmental perception which leads to their likeness or favourability, satisfied feeling or emotions. The organizations who are owing this attitude, for the environment have some level of respect ad create a feeling of protecting responsibility (Roeck \& Farooq, 2018). The affective attitude can become the part of life with interactions and relationships different experiences, effect of surrounded organizations, it can never trigger on its own. This type of influences will aggravate sadness or shame, emotional pride and will also provide guidelines to the organizations in never ending situations even their sense of responsibility will be triggered by a simple act of jealousy. The different sustainable approaches and decisions of the organizations are made on the behalf of surrounded events not only on their belief of sustainability (Morales \& Harris, 2014). The emotional state of an organization may lead them to feel joy, responsibility and respect for environment. Occasionally, an organization may have contradictory reaction rather than a building up positive feelings, which ultimately leads to take a decision for example they decided the adoption of sustainable practices because of worrying about climate changes (González-Hidalgo \& Zografos, 2019).

H1: Affective attitude has a significant relation to the adoption of sustainable technology.

The organizations who believed that their activities may contribute for producing a good product for them and their surroundings as well have cognitive attitude on environment. They might not be able to understand the importance of environment, but their activities can help them for the development of well empathetic and selecting an approach which will leads them to a well sustainable life. The cognitive attitude contains on situations of organizations, thoughts ideas or beliefs for a targeted object (bin Abu Bakar, 2017). According to the researcher the organizations who have a strong belief for completing a task or target will do their best doesn't matter how difficult it is. Because of the slow nature of degradation for the issues of environment the effect is sluggish, which leads in delaying their actions because of organizational perception that environmental issues are not crucial. their actions. Whereas the individuals who have a firm believe are confident that their small actions will make a contribution for achieving the better future (Mishra, Akman, \& 
Mishra, 2014). Around the sustainability their feelings will lead them towards the benefits of technology. Sánchez, Sánchez, and Hyder (2014), has stated that the organizations who doesn't modify their behaviour to environment it's not just because there is absence of environmental issues, but issue is, they don't believe on the claims of climate change, environmental issues.

H2: Cognitive attitude has a significant relation to the adoption of sustainable technology.

When the organization feel the responsibility of changing their behaviour by acting for the attainment of some benefits or specific purpose is known as behavioural attitudes. It is linked with responsibility that feels by the organization for acting on a certain rate (Kardooni, Yusoff, \& Kari, 2016). The behavioural instincts are known as the abilities of an organization to respond and performing an act either to approach or evade from certain condition. The socioeconomic system of making decision is affected by the Behavioural attitudes, which may change the structural lifestyle of the organization (bin Abu Bakar, 2017; Serenko \& Palvia, 2018). According to the literature organizational actions may trigger by the emotions and believes, which depends on the situations because their emotions will be determined by the actions when it's come to environment. The environmental outcomes are determined by the actions as Organizational behaviour have a significant impact. In general, personnel and social norms also effect the organizational behaviour. Sánchez et al. (2014) have stated that sustainable measures which organizations can do for being as obligatory, actions have changed now. For generating the adoption of sustainable practices emotions and beliefs are not essential, however according to Sánchez et al. (2014), for preventing the environment from additional damage all organizations must be involved or become the part of sustainability.

H3: Behavioural attitude has a significant relation to the adoption of sustainable technology.

According to the Pervan, Ansaari, and Xu (2015), the economic growth of all the organizations is related with its ability of searching alternate solutions or explanations like innovations. Reduction in luxurious purchasing, cumbersome investments and operational cost saving in long term are enabled with the application of sustainable technology. According to the Jeong, Jang, and Day (2014) Organizations can avoid the early shut down and get higher financial benefits with the implication of sustainable practices. Moreover, the production of goods and services related with sales growth can also be increased by sustainable practices. The product which accomplish the standards of sustainability is the part of internationalization process. The sustainable technology has been accepted as key factor of business in international market. Additionally, with less input resources, still we can achieve the growth, consequently organizations will get advantages from the long-term sustainable growth opportunities in both domestic and foreign markets (Bakar, 2017). The existing business operations may face some uncertain situations and may generate the restructuring or operational rebuilding, which at the same time may increase the business profitability and sustainability (Sutduean, Joemsittiprasert, \& Jermsittiparsert, 2019; Jermsittiparsert \& Wajeetongratana, 2019). According to the Choi, Narasimhan, and Kim (2016) by increasing the R\&D and improving the power of technology the overall profitability can be improved, as compared to the traditional method higher annual profits can be generated with the advanced sustainable technology (Karim et al., 2014). It is important for the organizations to shift to the other beneficial substitutes and reduce the consumption of natural resources, for the achieving the sustainability. The profits can also increase with reducing the cost of production. Earning maximum profit is the main objective of any organization, which can be attained with the implementation of sustainable practices and by using the available alternate resources (Choi et al., 2016). Organizations are expecting that use of advanced and sustainable technology will increase their profits. In underdeveloped countries the financial crises and cost cuttings are the organizational norms, and the organizations which encourage these norms search the solutions for the low cost and fast production without making compromise on the quality of product (Sodhro, Pirbhulal, \& Sangaiah, 2018). The substitutes involved in sustainable production may reduce the cost significantly for example in machinery and logistics and specifically managing the other 
expenses wisely for example traveling cost, activity cost ad operating cost. Organizations can also reduce the expenditure cost cause of hazards and accidents with the adoption of sustainable methods (Nadali, Zarifi, \& Shirsavar, 2017). Therefore, we can create the cost friendly, sustainable ad improved product. The competitiveness will be affected with the association between organizational performance and development. Competitive advantages can be achieved with the adoption of sustainable technologies, it can also increase the financial performance and enable the innovation examination (Guerrero-Baena, Gómez-Limón, \& Fruet, 2015; Haseeb, Hussain, Kot, Androniceanu, \& Jermsittiparsert, 2019). The countries which rely on exports have tendency to compete with the production of cheap items making fast deliveries and packaging and not bothering the environmental issues, are the result of competitiveness at international level. In that situation competitors can pressurize the other countries for the sustainable production of goods and services. SME's should compete at global level because of the globalization, attainment of sustainable technology will help them to compete internationally (Gupta \& Barua, 2016). It will also provide encouragement for the upgradation of functionality and quality in the form of sustainable technological innovation. Now a day's consumers are well aware to the market environment which caused the increase the demand of sustainable technology. Some countries have set certain requirements on the export products, that only those products will be exported which fulfil the environment friendly criteria. Due to this foreign pressure many organizations are encouraged to comprise the sustainable technology as a strategy of market expansion (Zhu, Cordeiro, \& Sarkis, 2013). The market breakthrough can be created for sustainable innovation with lower cost by using sustainable technology which will decrease cost of production. Although its general perception that sustainable technology is bit expensive, but the one who will initiate first will whisper production cost will be decreased and organization can easily penetrate in the market as compare to the competitors. Furthermore, for getting more clients and for the expansion of organizational market it is the best option to adopt the sustainable technology. For the SME's it is very difficult to compete with big organizations, so for the attractions of new customers strategy of adopting the sustainable approaches is a good option.

H4: Organizations have an expectation that sustainable technology will increase their economic performance.

Some prospects are created by sustainability for the organizations for the improving their environmental performance and for the societies to know about their social responsibility. For getting a stable income the organizations make crucial relationships with their customer ad it is also important to have prolonged relationships with repeated customers. Lita, Surya, and Syahrul (2014) have stated that around the sustainability the expectations of customers have positive impact on attitude of organization towards sustainability of industry. According to the literature the organizations with the adoption of innovations may compete with competitors and due to the innovations, their market value will be increased in similar industry. So, the top priorities for the development of modern sustainability are customer-oriented approaches and innovative practice (Park \& Kwon, 2017). Organizational performance can be improved, and competitiveness can be increased with the adoption of modern and sustainable methods, and as a result cost reduction will be promoted quality of the new products, process and services will be improved (Ploenhad, Laoprawatchai, Thongrawd, \& Jermsittiparsert, 2019; Jermsittiparsert \& Sommanawat, 2019; Sutduean, Singsa, Sriyakul, \& Jermsittiparsert, 2019). For a successful business only the best marketing strategies and good product is not enough you must have detailed knowledge about purchasing decisions and market demand (Michelsen \& Madlener, 2016). According to the literature the increase in number communities have started taking decisions as per the environmental awareness due to which demand for the sustainable oriented products is increased. So, the when an organization will adopt the sustainable practices it gives message to the public or customers that they really care about understanding the significant knowledge and environment. So, there will be a win-win situation for both the society and organizations, and it also help in improving their relationships. Local as well as the foreign investors will also attracted towards those countries which develop the sustainable practices, and it also build mutual trust among different countries. Because of global market 
requirements the foreign investors will also pressurize to the organizations for the adoption of sustainable modern technology (Zhu et al., 2013). Even with the same competitive products, the customers who have the environmental awareness will prefer more to sustainable and organic substitutes (Dvoráková \& Zborková, 2014). The meaning of philanthropy is love for the humanity which explains the sense of accountability or responsibility towards the society. The organizations which fulfil or meet the responsibilities of the society are known as philanthropic and for the maximization of profit the societal benefits must be the main objectives. Therefore, the organizations who are philanthropic as a part of their objective are tends to be people oriented. According to the Nally and Taylor (2015) for the improvement of the world the philanthropic thinking is a significant method. For the creation of better society all organizations should start focusing on the sustainable approaches. It's the obligation of every country to provide the heathier and safe place to its people that why the governments are more concerned for the creation of sustainable opportunities. Scholar have stated that international philanthropy can be beneficial for the underdeveloped countries who are suffering with financial crises. The profitable and non-profitable both organizations can create and implement the sustainable technologies by focusing on the prosperity of people, for the prosperity of people the creation of technologies modern education and trainings are important (Nally \& Taylor, 2015). For the more value creation, the organizations must always seek for changes which can help in increasing the resources of organization (Jarrar \& Smith, 2014). For the business support the organizations should be ensured about capacity of preserving the resources, which guarantee the ecological and economic stability. Additionally, with preservation of environment the organizations for certifying its long-term persistence must assess the effect of its used resources and investment value. Hempel and Hamm (2016) have stated organizational attitudes can be improved and increase the environmental and societal safety by the sustainable practices. The performance of the organization can be affected positively with the adoption of healthier lifestyle. The environmental wellbeing will eventually improve throughout the process. Govindan and Jepsen (2016) have stated by focusing on human health effect of sustainability in the form of need eliminates the poverty and for the employees expand the safety regulations. According to the scholar for the achievement of standard requirements safe and healthy organizations incorporates happiness, well-being, health, quality of life and personal responsibility. According to the researcher with the reduction in environmental risk we can achieve the social quality and human wellbeing. Open market available with new and decent job opportunities is step towards safe and healthy lifestyle. Following a sustainable lifestyle is not only a responsibility but also a source of creating satisfied and improved life. Nadali et al. (2017), have stated that in fact motivation of employees can be improved with decent working environment, it also increases the production ad decrease the negligence claims. Additionally, with the production of healthier and safe products prompts strong links between organizations and customers (Tidd \& Bessant, 2018). For the organizations the increasing cost of resources and energy generates unbelievable pressure so with the sustainable practices they improve and analyse their process continuously, they can also reduce their non-renewable resources with this kind of innovations. Regardless of the fact few studies show that end use price of sustainable and traditional resources is approximately same. For the organizations it can be reason to see the advantages over support of government policies (Moon, Bergey, \& Robinson, 2016). So, with the development of system we can manage process and procedures, price, can reduces the outputs of unsustainable products and can also achieve the minimum use of resources. It is hard for the organizations to survive in existing market, considering the further technology innovations without enough resources. The change in customer demand also shows the changes to be made in organizations, so the for the survival and fulfilling the customers' demands the required resources remain available (Cui, Jiao, \& Jiao, 2016).

H5: Organizations have an expectation that sustainable technology will increase their economic performance. 


\section{METHODOLOGY}

Regarding the Thailand SME's we had distributed survey questionnaires to total 327. SME 's of supports sector ad expected respond rate was 300 to 350 as according to the previous studies the response rate was around $0.2 \%$ of Thai SME's of different sectors. We intended the questionnaire for each organization's decision maker. So, we have considered all the responses from the respondent are organizational decisions. For the analysis stage of the current study we have used the PLS-SEM which is the main statistical tool. For the analysis the minimum required sample size is 10 times to the maximum number of variables of research model as per the studies of Hair, Hult, Ringle, and Thiele (2017) and Hair, Sarstedt, Hopkins, and Kuppelwieser (2014). According to the Hair, Hult, Ringle, and Sarstedt (2016) for the multivariate analysis the recommended sample size for each variable is 15 subjects.so for the current study the appropriate sample size is 315 respondents. Which will employee dependent and independent variables? Whereas we can accept large sample size because of two reasons (1) there is a probability of sampling error with the relying on small sample size, due to which targeted population cannot be reflected. (2) in small sample size there is prospect of biased effect. Specially if we are having non-normal data.

\section{Measurements}

Affective Attitudes

With the assessment of human emotional attachment to sustainable technology we have measured the affective attitudes. We have requested the organizations to give statements about their feelings for adopting the sustainable innovations. In the past Hair et al. (2014), and Matthes, Wonneberger, and Schmuck (2014) have used these measurements.

Cognitive attitudes

Around the judgements of sustainability and through the evaluated beliefs of organizations we have measured the cognitive attitudes, specifically in organization it creates concerned opportunities. We asked organizations rate the benefits or advantages of sustainability according to their opinion. According to the literature Hair et al. (2014) have used these items in their studies.

Behavioural Attitudes

We have measured the behavioural attitudes by the willingness of organizations ad their support for the adoption of sustainability. The level of willingness for the adoption of sustainable technology is indicated by the organizations. Author have used these items in their study.

Adoption of Sustainable Technology

For the measurement of organizational willingness by adopting the sustainable practices it is important to control their readiness to overcome problems for the achievement of success. It's also shown in existing research by Zolkepli and Kamarulzaman (2015).

\section{Data Analysis}

In the current study by using the PLS algorithm we have tested the data instrument for the evaluation of reflective measurement model (MM). the relevant MM (Figure 1), suitable reported results and evaluation criteria is studied by the PLS path model. For the quality judgment we have measured the data with predictive capabilities of theoretical research model by using PLS-SEM. Which enables the fair assessment of the construct measures validity and reliability. 


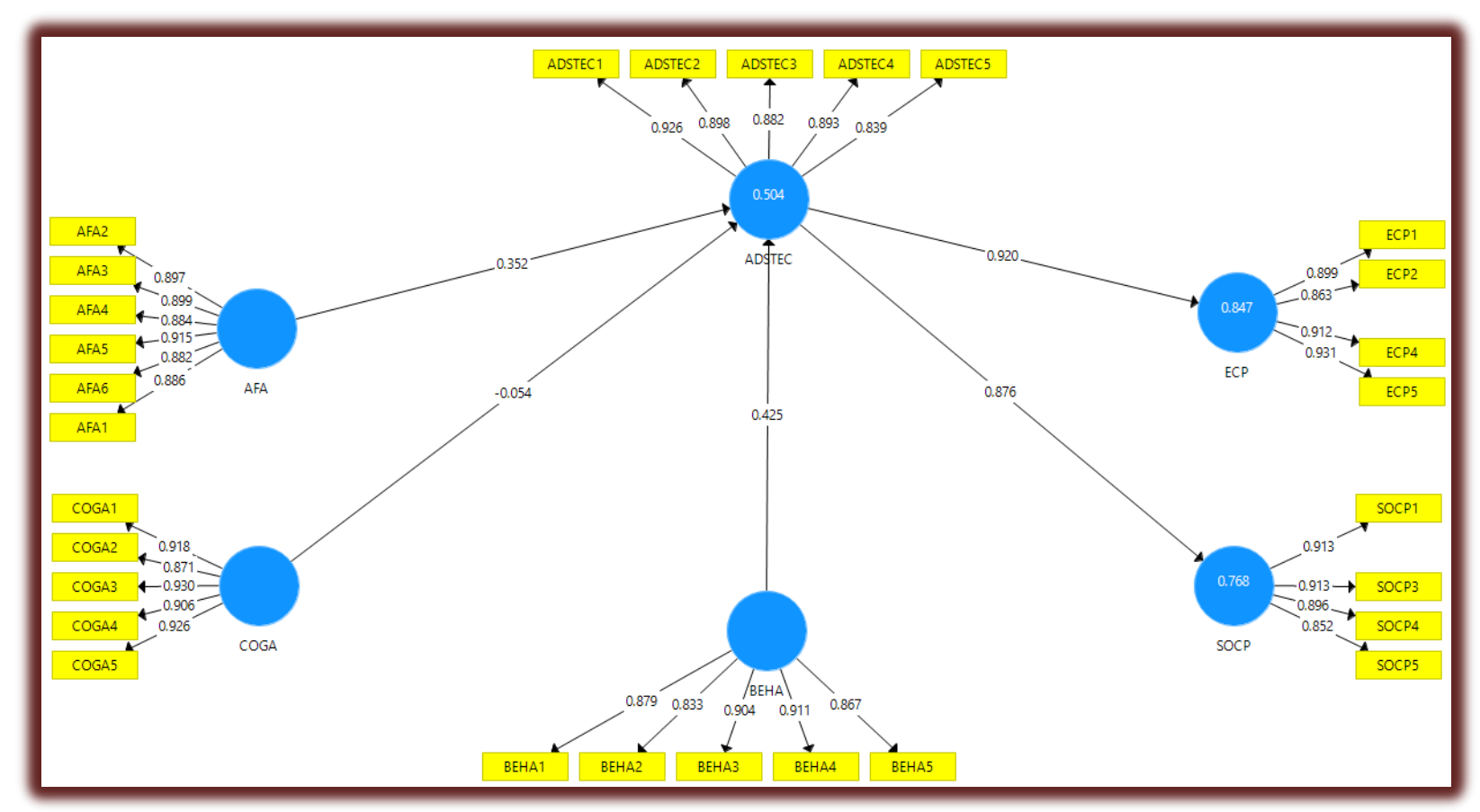

Figure 2. Measurement Model.

The outer loadings of all the variables must be significant statistically with the values greater than 0.708 . this indicate that shared change between the construct is greater than the measurement error change. Davcik and Sharma (2016), has stated that we should delete the values in between 0.40-0.70 only when it increases the value of AVE and composite reliability greater than the minimum threshold level. The higher values of outer loadings on construct shows that are a lot of common in the related indicators, which is also known as indicator reliability.

Table 1. Outer Loadings.

\begin{tabular}{|l|l|l|l|l|l|l|}
\hline & ADSTEC & AFA & BEHA & COGA & ECP & SOCP \\
\hline ADSTEC1 & 0.926 & & & & & \\
\hline ADSTEC2 & 0.898 & & & & & \\
\hline ADSTEC3 & 0.882 & & & & & \\
\hline ADSTEC4 & 0.893 & & & & & \\
\hline ADSTEC5 & 0.839 & & & & & \\
\hline AFA2 & & 0.897 & & & & \\
\hline AFA3 & & 0.899 & & & & \\
\hline AFA4 & & 0.884 & & & & \\
\hline AFA5 & & 0.915 & & & & \\
\hline AFA6 & & 0.882 & & & & \\
\hline BEHA1 & & 0.879 & & & \\
\hline BEHA2 & & 0.833 & & & \\
\hline BEHA3 & & & 0.904 & & & \\
\hline BEHA4 & & & 0.911 & & & \\
\hline BEHA5 & & & 0.867 & & & \\
\hline
\end{tabular}




\begin{tabular}{|l|l|l|l|l|l|l|}
\hline COGA1 & & & & 0.918 & & \\
\hline COGA2 & & & 0.871 & & \\
\hline COGA3 & & & 0.930 & & \\
\hline COGA4 & & & & 0.906 & & \\
\hline COGA5 & & & & 0.926 & & \\
\hline ECP1 & & & & 0.899 & \\
\hline ECP2 & & & & & 0.863 & \\
\hline ECP4 & & & & & 0.912 & \\
\hline ECP5 & & & & & 0.931 & \\
\hline SOCP1 & & & & & 0.913 \\
\hline SOCP3 & & & & & & 0.896 \\
\hline SOCP4 & & & & & & 0.852 \\
\hline SOCP5 & & & & & & \\
\hline AFA1 & & & & & & \\
\hline
\end{tabular}

Valuation of the theoretical research model valuation includes composite reliability (CR)for the assessment of internal consistency, reliability of organizational indicator, AVE for the assessment of discriminant validity (DV) and convergent validity (CV). Composite reliability is also known as internal consistency reliability, which is the advanced form of Cronbach' alpha. On the basis of inter correlations of observed variable indicators it gives the reliability estimates. High value shows the high level of reliability, and its range is between 0-1. Lonial and Carter (2015) stated that in the exploratory research the acceptable values of composite reliability are from $0.60-0.70$, whereas according to the advanced/modern research 0.70 and 0.90 are satisfactory values. By using the value of AVE, we have established and measured the convergent validity, which is equal to the construct's communality. The value of AVE equal to 0.50 or greater shows that the construct on average explain more than half of the total change in the variable. Equally if the value of AVE is less than 0.50 is shows that averagely there are more errors remains in items as compare to the change enlightened by the construct. AVE values as the assessment criterion builds the evaluation of convergent validity.

Table 2. Reliability.

\begin{tabular}{|l|l|l|l|l|}
\hline & Cronbach's Alpha & rho_A & CR & (AVE) \\
\hline ADSTEC & 0.933 & 0.934 & 0.949 & 0.789 \\
\hline AFA & 0.950 & 0.951 & 0.960 & 0.799 \\
\hline BEHA & 0.926 & 0.930 & 0.944 & 0.773 \\
\hline COGA & 0.948 & 0.951 & 0.960 & 0.829 \\
\hline ECP & 0.923 & 0.924 & 0.945 & 0.813 \\
\hline SOCP & 0.916 & 0.920 & 0.941 & 0.799 \\
\hline
\end{tabular}

Table 3. Discriminant Validity.

\begin{tabular}{|l|l|l|l|l|l|l|}
\hline & ADSTEC & AFA & BEHA & COGA & ECP & SOCP \\
\hline ADSTEC & 0.888 & & & & & \\
\hline AFA & 0.791 & 0.894 & & & & \\
\hline BEHA & 0.796 & 0.810 & 0.879 & & & \\
\hline COGA & 0.749 & 0.891 & 0.815 & 0.811 & & \\
\hline ECP & 0.720 & 0.773 & 0.725 & 0.770 & 0.901 & \\
\hline SOCP & 0.876 & 0.769 & 0.710 & 0.791 & 0.892 & 0.894 \\
\hline
\end{tabular}


The focus of the current research is on the theoretical model that signified the fundamental theory of the path model.

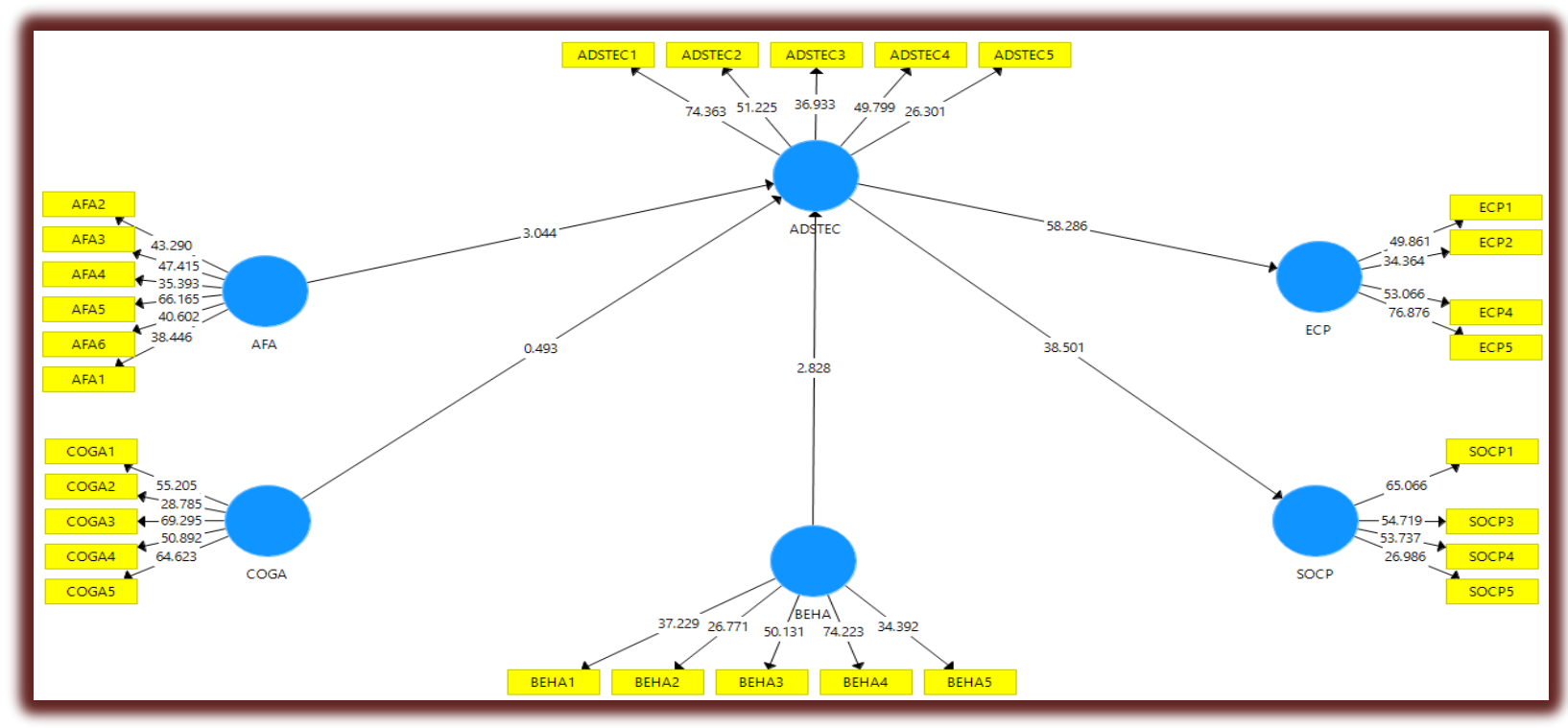

Figure 3. Structural model.

The outcomes of assessment will determine that how empirical data has maintained the theoretical framework ad defined in detail either the theory have explained well the phenomena. After the confirmation of reliability ad validity of the construct, we further evaluate the theoretical research model. Which involves in examination of predictive capabilities of model and association between variables. The important criteria for the assessment of structural model in PLS-SEM is the path coefficient significance, the degree of $R^{2}$ values, the effect size of $f^{2}$, the analytical relevance $Q^{2}$, and the $q^{2}$ affect size. We have obtained the estimates from structural model association which represents the hypothesized association between variables for the analysis of PLS-SEM, all the path coefficients have total standard values lies between -1 and +1 . The values of path coefficients which are close to +1 shows strong positive association whereas the values which are close to -1 shows negative association/relationship. The path coefficients close to 0 shows the weak relationship or known as insignificant. Though the significant values of variable can be estimated by path coefficients, eventually it depends on standard errors which we obtain from the bootstrapping. In bootstrapping from the original data set sub samples are strained randomly. Then for the estimation of model used each subsample. Ad repeated this process till the creation of many subsamples. Excluding the calculation of $t$ value, we have reported the $P$ values as well that are parallel to the rejection of null hypothesis in the current research. For the evaluation of Structural model (SM), the coefficient of determination is frequently used measurement, which is the degree of analytical model accuracy ad measured as square correlation among the predicted and actual values of independent variables. The coefficients show the combine effect of independent variables on dependent variables. And all the linked independent variables show the total change in dependent variables. 
Table 4. Direct relationship.

\begin{tabular}{|l|l|l|l|l|l|}
\hline & $(\mathbf{O})$ & $(\mathbf{M})$ & (STDEV) & $(|\mathbf{O} / \mathbf{S T D E V}|)$ & P Values \\
\hline ADSTEC $>$ ECP & 0.920 & 0.920 & 0.016 & 58.286 & $\mathbf{0 . 0 0 0}$ \\
\hline ADSTEC $->$ SOCP & 0.876 & 0.876 & 0.023 & 38.501 & $\mathbf{0 . 0 0 0}$ \\
\hline AFA $>$ ADSTEC & 0.352 & 0.348 & 0.116 & 3.044 & $\mathbf{0 . 0 0 1}$ \\
\hline BEHA $>$ ADSTEC & 0.425 & 0.422 & 0.150 & 2.828 & $\mathbf{0 . 0 0 2}$ \\
\hline COGA $>$ ADSTEC & -0.054 & -0.044 & 0.109 & 0.493 & $\mathbf{0 . 3 1 1}$ \\
\hline
\end{tabular}

The value of $R^{2}$ lies between $0-1$, high values show high level of accuracy. In the current study the value of $R^{2} 0.20$ and greater than is known as higher predictive accuracy. Additionally, for the assessment of scale for the values of $R^{2}$ is the criteria of assessing the predictive accuracy.

Table 5. R-square.

\begin{tabular}{|l|l|}
\hline & R Square \\
\hline ADSTEC & 0.504 \\
\hline ECP & 0.847 \\
\hline SOCP & 0.768 \\
\hline
\end{tabular}

The current study has also determined the value of $Q^{2}$. which is an indicator of predictive relevance of theoretical research model. For all the DV 's and AV's it correctly predicts data points of measurement construct. The values of $Q^{2}$ are greater than 0 for some DV's in theoretical research model which shows the predictive relevance of path model. By using the procedure of blindfolding we have obtained the values of $Q^{2}$, from a certain distance of omission.

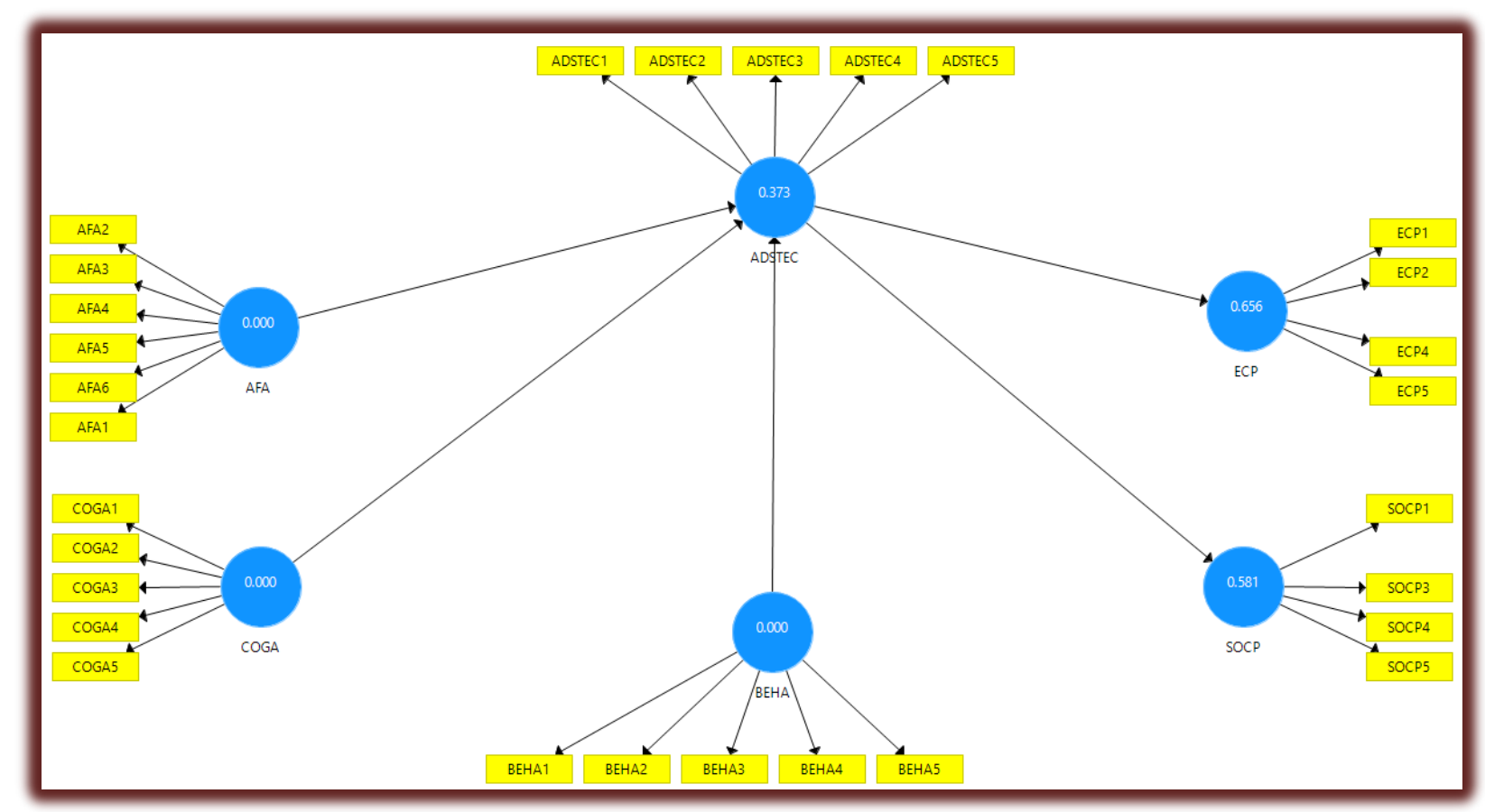

Figure 4. Q-square. 
Table 6. Q-square.

\begin{tabular}{|l|l|l|l|}
\hline & SSO & SSE & $\mathbf{Q}^{2}$ (=1-SSE/SSO) \\
\hline ADSTEC & $1,085.000$ & 680.370 & 0.373 \\
\hline AFA & $1,302.000$ & $1,302.000$ & \\
\hline BEHA & $1,085.000$ & $1,085.000$ & \\
\hline COGA & $1,085.000$ & $1,085.000$ & \\
\hline ECP & 868.000 & 298.743 & 0.656 \\
\hline SOCP & 868.000 & 363.558 & 0.581 \\
\hline
\end{tabular}

\section{CONCLUSION}

In the current study we have tested the model of modern theoretical research for the adoption of sustainable technology and by the adoption organization's expected outcomes. We have investigated the four factors government aid, organizational belief, organizational influences and organizational attitudes to see how these factors affect the decision-making process of the organizations with the adoption of sustainable technology. The results of the current study have supported the theoretical model of advanced research for the adoption of sustainable technology and confirmed the comparative contribution of the independent variables to the acceptance of changes in organizational sustainable technology. The results indicate the three types of path analysis taking adoption as DV, with organizational characteristics as control variable and adoption as DV ad and adoption as an IV. Though PLS -SEM has present the vibrant results, for theoretical framework more possibilities to be more appropriate to discuss about the SME'S in Thailand. The results of the current study will contribute to an improved theoretical consideration of the antecedents which effect the adoption of sustainable technology and its apparent outcomes. It provides practical implications for the NGOs and government as well. We have combined the Multiple variables in a single study which were used by different scholars in adoption related studies. Precise understandings have been made related to the aid of government for the adoption of sustainable technology, ethical beliefs of organizations, organizational persuasion and effects of organizational attitude.

\section{REFERENCES}

Bakar, M. F. (2017). Attitude towards adoption of sustainable technology by Malaysian SMEs and its impact on organizational performance.

Bin Abu Bakar, M. F. (2017). Attitude towards adoption of sustainable technology by Malaysian SMEs and its impact on organizational performance.

Chenhall, R. H., \& Moers, F. (2015). The role of innovation in the evolution of management accounting and its integration into management control. Accounting, organizations and society, 47, 1-13. https://doi.org/10.1016/j.aos.2015.10.002

Choi, K., Narasimhan, R., \& Kim, S. W. (2016). Opening the technological innovation black box: The case of the electronics industry in Korea. European Journal of Operational Research, 250(1), 192203. https://doi.org/10.1016/i.ejor.2015.08.054

Cui, Y., Jiao, J., \& Jiao, H. (2016). Technological innovation in Brazil, Russia, India, China, and South Africa (BRICS): an organizational ecology perspective. Technological Forecasting and Social Change, 107, 28-36. https://doi.org/10.1016/..techfore.2016.02.001

Davcik, N. S., \& Sharma, P. (2016). Marketing resources, performance, and competitive advantage: A review and future research directions. Journal of Business Research, 69(12), 5547-5552. https://doi.org/10.1016/j.jbusres.2016.04.169 
Dvořáková, L., \& Zborková, J. (2014). Integration of sustainable development at enterprise level. Procedia Engineering, 69, 686-695. https://doi.org/10.1016/j.proeng.2014.03.043

González-Hidalgo, M., \& Zografos, C. (2019). Emotions, power, and environmental conflict: Expanding the 'emotional turn'in political ecology. Progress in Human Geography. https://doi.org/10.1177/0309132518824644

Govindan, K., \& Jepsen, M. B. (2016). ELECTRE: A comprehensive literature review on methodologies and applications. European Journal of Operational Research, 250(1), 1-29. https://doi.org/10.1016/j.ejor.2015.07.019

Guerrero-Baena, M. D., Gómez-Limón, J. A., \& Fruet, J. V. (2015). A multicriteria method for environmental management system selection: an intellectual capital approach. Journal of Cleaner Production, 105, 428-437. https://doi.org/10.1016/j.jclepro.2014.07.079

Gupta, H., \& Barua, M. K. (2016). Identifying enablers of technological innovation for Indian MSMEs using best-worst multi criteria decision making method. Technological Forecasting and Social Change, 107, 69-79. https://doi.org/10.1016/..techfore.2016.03.028

Hair, Hult, G. T. M., Ringle, C., \& Sarstedt, M. (2016). A primer on partial least squares structural equation modeling (PLS-SEM): Sage publications. https://doi.org/10.3926/oss.37

Hair, Hult, G. T. M., Ringle, C. M., \& Thiele, K. O. (2017). Mirror, mirror on the wall: a comparative evaluation of composite-based structural equation modeling methods. Journal of the Academy of Marketing Science, 45(5), 616-632. https://doi.org/10.1007/s11747-017-0517-x

Hair, Sarstedt, M., Hopkins, L., \& Kuppelwieser, V. (2014). Partial least squares structural equation modeling (PLS-SEM) An emerging tool in business research. European Business Review, 26(2), 106-121. https://doi.org/10.1108/ebr-10-2013-0128

Haseeb, M., Hussain, H., Kot, S., Androniceanu, A., \& Jermsittiparsert, K. (2019). Role of Social and Technological Challenges in Achieving a Sustainable Competitive Advantage and Sustainable Business Performance. Sustainability, 11(14), 3811. https://doi.org/10.3390/su11143811

Hempel, C., \& Hamm, U. (2016). How important is local food to organic-minded consumers? Appetite, 96, 309-318. https://doi.org/10.1016/j.appet.2015.09.036

Jarrar, N. S., \& Smith, M. (2014). Innovation in entrepreneurial organisations: A platform for contemporary management change and a value creator. The British Accounting Review, 46(1), 60-76. https://doi.org/10.1016/j.bar.2013.07.001

Jeong, E., Jang, S. S., \& Day, J. (2014). The impact of eco-friendly practices on green image and customer attitudes: An investigation in a café setting. International Journal of Hospitality Management, 41, 10-20. https://doi.org/10.1016/j.ijhm.2014.03.002

Jermsittiparsert, K. \& Sommanawat, K. (2019). TQM, Human Oriented Elements and Organizational Performance: A Business Excellence Model for Higher Education Institutes of Thailand. International Journal of Innovation, Creativity and Change, 5(2), 514-532.

Jermsittiparsert, K. \& Wajeetongratana, P. (2019). The Firm's Strategic Orientations and Environmental Uncertainties as Antecedents of Its Supply Chain Agility. Humanities and Social Sciences Reviews, 7(2), 548-554. https://doi.org/10.18510/hssr.2019.7265

Kardooni, R., Yusoff, S. B., \& Kari, F. B. (2016). Renewable energy technology acceptance in Peninsular Malaysia. Energy Policy, 88, 1-10. https://doi.org/10.1016/j.enpol.2015.10.005

Karim, M., Phillips, M., \& Belton, B. (2014). Profitability and adoption of improved shrimp farming technologies in the aquatic agricultural systems of southwestern Bangladesh. Aquaculture, 428, 6170. https://doi.org/10.1016/j.aquaculture.2014.02.029

Lechevalier, S., Debanes, P., \& Shin, W. (2018). Financialization and Industrial Policies in Japan and Korea Evolving Complementarities and Loss of Institutional Capabilities. https://doi.org/10.2139/ssrn.3146968 
Lita, R. P., Surya, S., \& Syahrul, L. (2014). Green attitude and behavior of local tourists towards hotels and restaurants in West Sumatra, Indonesia. Procedia Environmental Sciences, 20, 261-270. https://doi.org/10.1016/j.proenv.2014.03.033

Lucangioli.S. "Acute Renal Failure: An Article Critique." International Journal of Pharmacy Research \& Technology 8.2 (2018), 51-52. Print. https://doi.org/10.31838/ijprt/08.02.07

Matthes, J., Wonneberger, A., \& Schmuck, D. (2014). Consumers' green involvement and the persuasive effects of emotional versus functional ads. Journal of Business Research, 67(9), 1885-1893. https://doi.org/10.1016/j.jbusres.2013.11.054

Michelsen, C. C., \& Madlener, R. (2016). Switching from fossil fuel to renewables in residential heating systems: An empirical study of homeowners' decisions in Germany. Energy Policy, 89, 95-105. https://doi.org/10.1016/j.enpol.2015.11.018

Mishra, D., Akman, I., \& Mishra, A. (2014). Theory of reasoned action application for green information technology acceptance. Computers in Human Behavior, 36, 29-40. https://doi.org/10.1016/j.chb.2014.03.030

Moon, S., Bergey, P. K., \& Robinson, S. (2016). Message framing and individual traits in adopting innovative, sustainable products (ISPs): Evidence from biofuel adoption. Journal of Business Research, 69(9), 3553-3560. https://doi.org/10.1016/j.jbusres.2016.01.029

Morales, M. C., \& Harris, L. M. (2014). Using subjectivity and emotion to reconsider participatory natural resource management. World Development, 64, 703-712. https://doi.org/10.1016/j.worlddev.2014.06.032

Nadali, S., Zarifi, S., \& Shirsavar, H. (2017). Identifying and ranking the supply chain management factors influencing the quality of the products. Uncertain Supply Chain Management, 5(1), 43-50. https://doi.org/10.5267/j.uscm.2016.8.001

Nally, D., \& Taylor, S. (2015). The politics of self-help: The Rockefeller Foundation, philanthropy and the 'long'Green Revolution. Political Geography, 49, 51-63. https://doi.org/10.1016/j.polgeo.2015.04.005

Park, E., \& Kwon, S. J. (2017). What motivations drive sustainable energy-saving behavior?: An examination in South Korea. Renewable and Sustainable Energy Reviews, 79, 494-502. https://doi.org/10.1016/j.rser.2017.05.150

Pervan, S., Ansaari, Y., \& Xu, J. (2015). Environmental determinants of open innovation in Dubai SMEs. Industrial Marketing Management, 50, 60-68. https://doi.org/10.1016/j.indmarman.2015.05.029

Ploenhad, J., Laoprawatchai, P., Thongrawd, C., \& Jermsittiparsert, K. (2019). Mediating Role of Competitive Advantage on the Relationship of Supply Chain Management and Organizational Performance on the Food Industry of Thailand. International Journal of Supply Chain Management, 8(4), 216-226.

Roeck, K., \& Farooq, O. (2018). Corporate social responsibility and ethical leadership: Investigating their interactive effect on employees' socially responsible behaviors. Journal of Business Ethics, 151(4), 923-939. https://doi.org/10.1007/s10551-017-3656-6

Roopa Satyanarayan Basutkar, Tenzin Tsundue, Hema Siva, Anju Rose, Sivasankaran Ponnusankar. "Vitamin D Supplementation in Patients with Iron Deficiency Anaemia: A Systematic Review and a Meta-Analysis." Systematic Reviews in Pharmacy 10.1 (2019), 1-10. https://doi.org/10.5530/srp.2019.1.1

Sánchez, F. J., Sánchez, C., \& Hyder, A. (2014). The role of personal involvement, credibility and efficacy of conduct in reported water conservation behaviour. Journal of Environmental Psychology, 38, 206216. https://doi.org/10.1016/j.jenvp.2014.02.003

Serenko, A., \& Palvia, P. (2018). Top IT Issues for Employers of South African Graduates. Paper presented at the ICT Education: 47th Annual Conference of the Southern African Computer 
Lecturers' Association, SACLA 2018, Gordon's Bay, South Africa, June 18-20, 2018, Revised Selected Papers. https://doi.org/10.1007/978-3-030-05813-5_8

Sodhro, A. H., Pirbhulal, S., \& Sangaiah, A. K. (2018). Convergence of loT and product lifecycle management in medical health care. Future Generation Computer Systems, 86, 380-391. https://doi.org/10.1016/i.future.2018.03.052

Sutduean, J., Joemsittiprasert, W., \& Jermsittiparsert, K. (2019). Uncertainty As an Antecedent of the Supply Chain Risk: Does Supply Chain Flexibility Matter in Risk Mitigation?. Humanities and Social Sciences Reviews, 7(2), 503-509. https://doi.org/10.18510/hssr.2019.7259

Sutduean, J., Singsa, A., Sriyakul, T., \& Jermsittiparsert, K. (2019). Supply Chain Integration, Enterprise Resource Planning, and Organizational Performance: The Enterprise Resource Planning Implementation Approach. Journal of Computational and Theoretical Nanoscience, 16(7), 29752981. https://doi.org/10.1166/jetn.2019.8204

Tidd, J., \& Bessant, J. R. (2018). Managing innovation: integrating technological, market and organizational change: John Wiley \& Sons.

Zhu, Q., Cordeiro, J., \& Sarkis, J. (2013). Institutional pressures, dynamic capabilities and environmental management systems: Investigating the ISO 9000-Environmental management system implementation linkage. Journal of environmental management, 114, 232-242. https://doi.org/10.1016/i.jenvman.2012.10.006

Zolkepli, I. A., \& Kamarulzaman, Y. (2015). Social media adoption: The role of media needs and innovation characteristics. Computers in Human Behavior, 43, 189-209. https://doi.org/10.1016/i.chb.2014.10.050

\section{@(@) $\Theta \Theta$}

This work is licensed under a Attribution-NonCommercial-NoDerivatives 4.0 International (CC BY-NC-ND 4.0). 